\title{
Reinstatement of Xanthomonas citri (ex Hasse) and X. phaseoli (ex Smith) to Species and Reclassification of All $X$. campestris pv. citri Strains $\dagger^{\dagger}$
}

\author{
D. W. GABRIEL, ${ }^{1 *}$ M. T. KINGSLEY, ${ }^{1}$ J. E. HUNTER,${ }^{2}$ AND T. GOTTWALD ${ }^{3}$ \\ Plant Pathology Department, University of Florida, Gainesville, Florida $32611^{1}$; Department of Plant Pathology, \\ New York State Agricultural Experiment Station, Cornell University, Geneva, New York $14456^{2}$; and U.S. Department of \\ Agriculture-Agricultural Research Service, 2120 Camden Road, Orlando, Florida $32803^{3}$
}

\begin{abstract}
A recent epiphytotic disease on citrus in Florida nurseries was caused by strains of Xanthomonas campestris with different host specificity and lower pathogenic capacities than those of previously described strains of $X$. campestris pv. citri. The new strains were classified as $X$. campestris pv. citri because they were isolated from rutaceous hosts and despite the fact that they caused a different disease than strains previously described in that pathovar. Restriction fragment length polymorphism analyses revealed that the Florida strains comprised a heterogeneous (E) group, interrelated with $X$. campestris pv. alfalfae, $X$. campestris pv. cyamopsidis, and $X$. campestris pv. dieffenbachiae. In contrast, the previously described strains of $X$. campestris pv. citri formed two highly distinct, homogeneous (A and B/C/D) groups. Furthermore, the strains of $X$. campestris pv. campestris, $X$. campestris pv. glycines, $X$. campestris pv. malvacearum, X. campestris pv. phaseoli, X. campestris pv. pisi, and $X$. campestris pv. vignicola tested were also distinctive and appeared to be only distantly related to one another and to all $X$. campestris pv. citri strains. We concluded (i) that some pathovars are sufficiently distinct from the type strain of the species $X$. campestris to be considered as separate species, (ii) that $X$. campestris pv. citri group $A$ and $X$. campestris pv. phaseoli (not including $X$. campestris pv, phaseoli var. fuscans) represent distinctly separate subbranches of the genus and should be respectively reinstated to species as $X$. citri (ex Hasse) nom. rev. 3213 and $X$. phaseoli (ex Smith) nom. rev. G27, and (iii) that the $X$. campestris pv. citri $\mathrm{B} / \mathrm{C} / \mathrm{D}$ strains and the heterogeneous $\mathrm{E}$ strains should be respectively renamed $X$. campestris pv. aurantifolii $\mathrm{pv}$. nov, and $X$. campestris pv. citrumelo pv. nov.
\end{abstract}

Strains of Xanthomonas campestris (Pammel 1895) Dowson 1939 pv. citri cause five different diseases of citrus, based on host species specificity and symptoms. The A group of strains induces the disease citrus canker and is the most damaging for any citrus host. These strains also attack the largest number of citrus species: Citrus sinensis (sweet orange), $C$. paradisi (grapefruit), C. limon (lemon), C. reticulata (mandarin), and C. aurantifolia (Mexican lime) (24). The B group of strains induces disease symptoms termed cankrosis B or false citrus canker (7). Compared with the A group, the B strains are more restricted in host range, attacking mainly lemon and Mexican lime (24). The single extant $\mathrm{C}$ strain is known to be pathogenic only for Mexican lime (24) and causes the disease Mexican lime cankrosis (3). The D group of strains is considered to cause yet another disease, Mexican bacteriosis (3), but this disease has not been well characterized. Finally, the recent epiphytotic disease in citrus nurseries was determined to be caused by $X$. campestris pv. citri (21) group $\mathrm{E}$ (9). The $\mathrm{E}$ group of strains causes citrus bacterial spot or Florida nursery canker, also a distinct disease with mild symptoms and yet different host species specificity. The $\mathrm{E}$ strains were found only on young plants in nurseries and predominantly in association with the rootstock variety Swingle citrumelo $(C$. paradisi $\times$ Poncerus trifoliata) (21).

Among $X$. campestris pathovars there is "substantial genetic, physiological and serological diversity, which in other bacterial groups is accepted as valid delineation at the species level" (25). For example, DNA-DNA homologies

\footnotetext{
* Corresponding author.

$\uparrow$ Florida Agricultural Experiment Station journal series contribution 9128 .
}

between strains of four $X$. campestris pathovars were quite low, ranging from 4 to $21 \%$ (26). Generally, DNA-DNA homologies of $>60 \%$ are expected of strains within a species $(11,20)$. Recently, protein and DNA analytical methods have been used to examine strain-specific variation in $X$. campestris $(15,16,27)$. Restriction fragment length polymorphism (RFLP) comparisons of total DNAs from strains of 23 different pathovars have demonstrated that some pathovars, such as $X$. campestris pv. phaseoli, are composed of distinguishable clonal groups (16). RFLP tests of previously described $X$. campestris pv. citri strains reveal two distinct clonal groups, corresponding to the $\mathrm{A}$ and $\mathrm{B} / \mathrm{C} / \mathrm{D}$ pathogenicity groups, which are distinct from all other pathovars tested (5). A proposal that $X$. campestris pv. campestris, $X$. campestris pv. carotae, $X$. campestris pv. malvacearum, $X$. campestris pv. phaseoli, and $X$. campestris pv. translucens be reinstated as species on the basis of protein profiles has recently been made (M. L. Derie, and N. W. Schaad, submitted for publication). Although protein and DNA tests are not simple to perform, in at least some cases they appear to provide reasonably objective, reproducible, and consistent methods for strain classification of Xanthomonas species.

The classification of Xanthomonas strains as pathovars is unsatisfactory, because the bacterium is not classified by its intrinsic qualities alone but rather by the pathogenic reaction phenotype of a plant. Ideally, and in accordance with the International Code of Nomenclature of Bacteria, strains of $X$. campestris that cause different disease reactions on different host species should be placed in different pathovars (13). In practice, however, the suggested taxonomic code is not rigorously applied; as noted above, strains known to cause five different diseases have been included in $X$. cam- 
pestris pv. citri. In the Florida epiphytotic disease caused by the $\mathrm{E}$ strains of $X$. campestris pv. citri, the ambiguity inherent in the pathovar classification system allowed strains that cause a relatively minor disease (8) to cause a major economic problem because they were classified as the same pathovar that causes citrus canker. By law, action had to be taken to destroy trees infected with $X$. campestris pv. citri. Over 20 million citrus trees have been destroyed in the citrus canker eradication program, causing well over \$25 million in damage (21).

The purpose of this work was (i) to assess the level of RFLP variation among a select group of $X$. campestris pv. citri $\mathrm{E}$ strains which exhibit variable pathogenicity, (ii) to see whether the observed genetic variation correlated with the pathogenic variation, (iii) to develop an objective criterion (independent of pathogenicity tests) that might be used to define the E group, and (iv) to determine a more appropriate classification scheme for strains included in $X$. campestris pv. citri. As a result of these and previously published RFLP analyses $(5,16)$, we conclude that $X$. campestris pv. citri is an inappropriate designation for any of the strains classified as $X$. campestris pv. citri.

We propose that the A group of $X$. campestris pv. citri be reinstated to species as $X$. citri (ex Hasse), that $X$. campestris pv. phaseoli be reinstated to species as $X$. phaseoli (ex Smith), that the B, C, and D strains of $X$. campestris pv. citri be classified as $X$. campestris pv. aurantifolii pv. nov., and that the $\mathrm{E}$ strains be designated as $X$. campestris pv. citrumello pv. nov. In the rest of this paper, we use the names $X$. citri, $X$. phaseoli, $X$. campestris pv. aurantifolii, and $X$. campestris pv. citrumello as indicated.

\section{MATERIALS AND METHODS}

Bacterial strains. All strains from citrus were originally isolated and confirmed to be pathogenic to citrus by the Division of Plant Industry, Florida Department of Agriculture, Gainesville. Strains were stored as $15 \%$ glycerol stocks at $-70^{\circ} \mathrm{C}$ soon after their isolation by us or by $R$. Stall (University of Florida, Gainesville). All culture designations are Division of Plant Industry log entries and can be traced to the location, date, and host of original isolation. All work with strains pathogenic to citrus was performed at the BL-2 containment level. Strain 82.1 ( $X$. campestris pv. alfalfae) was provided by R. Stall. Strains L-334 and L-676 $(X$. campestris pv. alfalfae) were provided by F. Lukezic (Pennsylvania State University, State College). Strain $\mathrm{G} 27^{\mathrm{T}}(X$. phaseoli) was subcultured from (and is probably synonymous with) strain LB-2, provided by A. Vidaver (University of Nebraska, Lincoln). The type strain ATCC $33913^{\mathrm{T}}$ $\left(=\right.$ NCPPB $\left.^{2} 8^{\mathrm{T}}\right)$ of $X$. campestris was obtained from the American Type Culture Collection. All other strains and sources were previously published; strains named ph2, ph8, ph5, and ph3 (5) are synonymous with G62, JF, Xph25, and Xpa (16), respectively. All strains were confirmed as pathogenic on the appropriate host(s).

DNA manipulations and similarity coefficients. All DNA extractions, subsequent gel electrophoresis, and Southern blots were as previously described for plasmid (14) or chromosomal DNA (16) preparations. The DNA probes used in this study were pUFA-704, carrying a 32-kilobase $X$. campestris pv. malvacearum DNA insert, and pUFT1 (synonymous with XCT1), carrying a 30-kilobase $X$. campestris pv. citrumelo DNA insert. Similarity coefficients were determined as described previously by using a Gilford Response II integrating spectrophotometer, which determined the origin plus the 11 most strongly hybridizing DNA fragments by peak height (5). The computer-selected strongest hybridizing bands from each track were matched $( \pm 1 \mathrm{~mm}$ absolute location on a $150-\mathrm{mm}$ scale) against bands appearing in the other tracks. The number of major bands which matched and the total number of major bands in each pairwise comparison were tallied. Comparative data from each probe-enzyme combination were totalled, and similarity coefficients between two strains were calculated, as previously described (5), with the following estimator of DNA fragment homology $(F): \hat{F}=\left(n_{\mathrm{xy}}+n_{\mathrm{yx}}\right) /\left(n_{\mathrm{x}}+n_{\mathrm{y}}\right)$, where $n_{\mathrm{x}}$ and $n_{\mathrm{y}}$ are the numbers of major fragments in strains $\mathrm{X}$ and $\mathrm{Y}$, respectively, $n_{\mathrm{xy}}$ is the number of major fragments in strain $X$ which match any fragments in strain $Y$, and $n_{\mathrm{yx}}$ is the number of major fragments in strain $\mathrm{Y}$ which match any fragments in strain $X$. Cluster analysis by the unweighted average pair group method (23) was performed with the Clustan program (28).

Microbial enzyme and spectrophotometer tests. Cultures of $X$. campestris were maintained at room temperature for up to 2 weeks on lima bean agar (Difco Laboratories, Detroit, Mich.) plates, $\mathrm{pH}$ 7.4. $X$. campestris was grown in three different media based on a morpholinepropanesulfonic acid (MOPS)-buffered salts medium (pH 7.4) (18). This MOPSbuffered salts medium was made essentially as previously described (18) and modified for $X$. campestris by adding $\mathrm{CaCl}_{2}$ to a final concentration of $0.1 \mathrm{mM}$ and omitting $\mathrm{NaCl}$. Overnight Xanthomonas cultures were grown in the modified MOPS medium supplemented with $2 \%$ (wt/vol) peptone (POPS) or with $0.5 \%$ tryptone plus $0.3 \%$ yeast extract and $0.09 \% \mathrm{CaCl}_{2}-2 \mathrm{H}_{2} \mathrm{O}$ (TY-MOPS). Nutritional requirements of strains were checked on modified MOPS minimal medium made with glass-distilled water, solidified with $1.5 \%$ (wt/vol) Noble agar (Difco) and containing $1 \%$ glycerol as a carbon source (MOPS-minimal). (The MOPS medium contained $0.05 \% \mathrm{NH}_{4} \mathrm{Cl}$ as a nitrogen source.) Strains were tested by standard methods for proteolysis of milk (6) and hydrolysis of starch (amylase) (17), pectin $(10,19)$, and Tween 80 (lipase) (6). Pigment was extracted from ca. $2 \mathrm{ml}$ of late-logto-stationary phase cultures by pelleting cells and boiling the cells at $90^{\circ} \mathrm{C}$ in $2 \mathrm{ml}$ of $100 \%$ methanol for $10 \mathrm{~min}$. Additional methanol was added to replace that lost to evaporation; at no time was the methanolic extract allowed to evaporate to dryness. The methanol extract was cooled to room temperature and scanned over wavelengths of 300 to $600 \mathrm{~nm}$ to determine the absorption spectrum with a self-calibrating Gilford Response II spectrophotometer.

Pathogenicity tests and growth kinetic studies on whole plants. For plant symptom assays, cells were pelleted, suspended in tap water, and diluted to $10^{4}$ to $10^{5} \mathrm{CFU} / \mathrm{ml}$. Inoculations of citrus were performed with tuberculin syringes to infiltrate the spongy mesophyl at 6 to 8 locations per tender, newly expanded leaves of Duncan grapefruit $(C$. paradisi) or Swingle citrumelo $(C$. paradisi $\times P$. trifoliata) seedlings. In these tests, a half-leaf assay was used, with two cultures inoculated per leaf, one on the left side of the midvein and one on the right. Inoculations onto Medicago sativa $\mathrm{cv}$. Florida 77 were performed by using the blunt end of a tuberculin syringe to pressure infiltrate the mesophyl through open stomata. Inoculations onto Phaseolus vulgaris cv. Contender (Fredonia Seeds, Fredonia, N.Y.) or cv. California Light Red (Agway Corporation Beanplant, Ithaca, N.Y.) were similarly performed on mature, fully expanded trifoliate leaves.

For studies of growth kinetics in planta, cultures of $X$. campestris were grown on lima bean agar plates for $48 \mathrm{~h}$ at 
$28^{\circ} \mathrm{C}$, suspended in sterile tap water, and diluted to ca. $5 \times$ $10^{5} \mathrm{CFU} / \mathrm{ml}$. For bean inoculations, each culture was pressure infiltrated as described before into mature trifoliolate leaves. Three $0.5-\mathrm{cm}$ spots were inoculated per leaf, and three individual leaves per strain were taken per sampling. For citrus inoculations, each culture was pressure infiltrated into the leaf so that the entire leaf was soaked. We verified the actual titers of all inocula by plate counts. The average titers at time zero were $5 \times 10^{3} \mathrm{CFU}$ per bean leaf and $5 \times$ $10^{3} \mathrm{CFU} / \mathrm{cm}^{2}$ of citrus leaf.

Sampling of the bean leaves was performed by grinding the leaf tissue in sterile mortars and gradually adding $5 \mathrm{ml}$ of sterile tap water. Sampling of the citrus leaves was performed by cutting 7-mm-diameter disks from the inoculation zones with a sterile cork borer. For each sample taken, disks were removed from three different leaves inoculated with the same culture and ground in sterile 7-ml glass tissue homogenizers with $1 \mathrm{ml}$ of sterile tap water. Appropriate dilutions were plated onto TY-MOPS medium supplemented with 50 $\mu \mathrm{g}$ of kasugamycin (Sigma Chemical Co., St. Louis, Mo.) per $\mathrm{ml}$ to reduce growth of opportunistic saprophytic bacteria. Kasugamycin is a useful addition to semiselective media (4), since many xanthomonads, including all of those tested here, are naturally resistant to this antibiotic. Each experiment was repeated at least twice.

Detached citrus leaf assay for pathogenicity. For doubleblind detached-leaf assays, young Swingle citrumelo leaves ( $1 / 3$ to $1 / 2$ expanded) were detached from the plant, surface sterilized with $10 \%$ commercial bleach, rinsed in sterile distilled water, and placed on water agar plates (1.0\% agar). A standard 2-in. $(5.08-\mathrm{cm})$ steel sewing needle was used to make 8 to 10 single puncture wounds per leaf. Cells from coded overnight cultures were pelleted and suspended in tap water to ca. $10^{8} \mathrm{CFU} / \mathrm{ml}$, and $10-\mu \mathrm{l}$ droplets were placed directly onto the puncture wound sites on citrus leaves. Each strain tested was inoculated onto all of the wound sites of a leaf, and each leaf was visually scored with the aid of a stereomicroscope. The degrees of water soaking, chlorosis, and necrosis were assessed for each leaf. All scores were made relative to a control strain of $X$. campestris $\mathrm{pv}$. citrumelo on a 0 (low)-to-3 (high) scale. Six individual leaves were used per strain tested, and the averaged results are reported.

\section{RESULTS}

Strain characteristics and RFLP analyses. For strain characteristic and RFLP comparisons, we chose $15 X$. campestris pv. citrumelo strains isolated from different geographic locations within Florida that elicited the widest possible range of symptoms. The range of disease symptoms was first noticed at the original field sites or during subsequent greenhouse tests (or both) and is reflected in the detachedleaf assays run on most of the strains compared in Table 1. Also provided in Table 1 are some additional strain characteristics, including plasmid analyses and enzyme assay results. The RFLP comparisons are shown in Fig. 1, and the computer-selected bands from tracks run on the same gel are quantitatively compared in Table 2 . Methanol extractions of the bright yellow pigment from all of the strains exhibited a major absorption peak between 443 and $446 \mathrm{~nm}$. All of the strains grew on MOPS minimal medium, although $X$. citri strains grew slowly on this medium. RFLP comparisons of as many different $X$. campestris pv. alfalfae strains as we could find are in Fig. 1, and the derived coefficients are presented in Table 3. Figure 2 is a composite dendrogram of 48 Xanthomonas strains obtained by performing cluster analyses on the similarity coefficients from Tables 2 and 3 , combined with previously published data $(5,16)$.

On the basis of RFLP analyses, the $X$. campestris pv. citrumelo strains comprised two somewhat related groups (E1 and E2) and three less related strains (cf. Table 2). All strains of the E2 group tested carried a 41-kilobase plasmid (Table 1) and were all highly related ( $>89 \%$ similarity; Table 2). However, all were from nurseries related by crossshipments of citrus host plants, and therefore the clonality of the group is probably not ecologically significant but rather an artifact due to the movement of the citrus hosts. Similarly, the most highly related of the E1 strains (3401, 0329, and 4600) were isolated from nurseries related by citrus plant shipments. Within the E1 group, five strains (0634, 7364, 6260,4827 , and 3401 ) are not known to be related by nursery stock sales, despite extensive efforts on the part of the Florida Division of Plant Industry and the U.S. Department of Agriculture Animal and Plant Health Inspection Service to link infestations (C. Schoulties, personal communication). These strains of $X$. campestris pv. citrumelo were moderately to highly related $(\hat{F}$ values ranging from $49 \%$ to $82 \%$ similarity), and their independent isolation in unrelated nurseries may be evidence of ecological fitness for certain citrus varieties.

Except for the E1 group, strains of $X$. campestris pv. citrumelo were no more related to one another than they were to $X$. campestris pv. alfalfae ( $40 \%$ or less similarity; $\mathrm{cf}$. Tables 2 and 3 and Fig. 2). The strains of $X$. campestris pv. alfalfae were only moderately related ( $\hat{F}$ values ranging from $40 \%$ to $71 \%$ similarity), a result similar to that observed with $X$. campestris pv. citrumelo. If the $X$. campestris pv. citrumelo strains known to be related by nursery stock sales are discounted, high levels $(>85 \%)$ of similarity were not seen among any of the $X$. campestris pv. alfalfae or $X$. campestris pv. citrumelo strains. Strains of $X$. campestris pv. alfalfae, $X$. campestris pv. cyamopsidis, and $X$. campestris pv. citrumelo did not form distinct clusters but rather formed a heterogeneous collection of moderately related strains (Fig. 2). RFLP tests could be used for strain identification, but classification of unknown strains of these heterogeneous pathovars could not easily be accomplished by using these RFLP tests.

In sharp contrast to the above results, strains of $X$. citri, $X$. campestris pv. aurantifolii strains B and D (but not C), and $X$. phaseoli (not including $X$. campestris pv. phaseoli var. fuscans strains, which are distinct [16]) were tightly clustered, with similarity coefficients of $85 \%$ or more (Fig. 2). Regardless of geographic origin or time of isolation, strains of $X$. citri and $X$. phaseoli form distinct subbranches of the genus. Whether isolated in Brazil, Japan, Reunion Island, or Florida, there was no evidence for less than $80 \%$ similarity among strains of $X$. citri. Similarly, whether isolated in Florida, Nebraska, Missouri, Kansas, New York, or Wisconsin, there was no evidence for less than $80 \%$ similarity among strains of $X$. phaseoli. These similarity levels were obtained by using enzyme-probe combinations capable of discriminating strains of the genus at the $10 \%$ similarity level.

Whole-plant pathogenicity tests. The close resemblance of some $X$. campestris pv. citrumelo and $X$. campestris pv. alfalfae strains by RFLP comparisons led to comparisons of the strains by pathogenicity tests. Since the reported host range of $X$. campestris pv. alfalfae is $M$. sativa (alfalfa) and $P$. vulgaris (common bean) (1), pathogenicity tests were 
TABLE 1. Summary of genetic, microbial, and pathogenicity test analyses of $X$. campestris pv. citrumelo strains in comparison with those of selected Xanthomonas strains

\begin{tabular}{|c|c|c|c|c|c|c|c|c|c|c|c|c|}
\hline \multirow{3}{*}{ Strain } & \multirow{3}{*}{$\begin{array}{l}\text { Source or } \\
\text { reference }\end{array}$} & \multirow{3}{*}{ Amylase } & \multirow{3}{*}{ Casein } & \multirow{3}{*}{ Lipase } & \multirow{3}{*}{$\begin{array}{c}\text { pH } 5 \\
\text { pectin }^{a}\end{array}$} & \multirow{3}{*}{$\begin{array}{c}\mathrm{pH} 7 \\
\text { pectin }^{a}\end{array}$} & \multirow{3}{*}{$\begin{array}{l}\text { FPA } \\
\text { pectin }^{a}\end{array}$} & \multirow{3}{*}{$\begin{array}{l}\text { RFLP } \\
\text { group }\end{array}$} & \multirow{3}{*}{$\begin{array}{c}\text { Plasmid } \\
\text { size } \\
(\mathrm{kb})\end{array}$} & \multicolumn{3}{|c|}{$\begin{array}{l}\text { Pathogenicity assay }{ }^{b} \text { results } \\
\text { with: }\end{array}$} \\
\hline & & & & & & & & & & \multicolumn{2}{|c|}{ Whole plant } & \multirow{2}{*}{$\begin{array}{l}\text { Detached } \\
\text { citrus leaf }\end{array}$} \\
\hline & & & & & & & & & & Citrus & Alfalfa & \\
\hline \multicolumn{13}{|c|}{ X. campestris pv. citrumelo } \\
\hline 3401 & 5 & + & + & + & $+1-$ & $+1-$ & $+1-$ & E1 & $\mathbf{0}$ & + & $+1-$ & 0.00 \\
\hline 0169 & Here & + & + & + & + & + & + & E1 & 0 & + & $\mathrm{ND}^{c}$ & ND \\
\hline 0329 & 5 & + & + & + & + & + & + & E1 & ND & + & ND & 0.15 \\
\hline 4600 & 5 & + & + & + & + & + & + & E1 & 67 & + & $+1-$ & 0.04 \\
\hline 4755 & 5 & + & + & + & + & + & + & E1 & ND & + & ND & 0.08 \\
\hline 4827 & Here & ND & ND & ND & ND & ND & ND & E1 & ND & + & $+1-$ & 0.24 \\
\hline 6260 & 5 & ND & ND & ND & ND & ND & ND & E1 & ND & + & ND & ND \\
\hline 7364 & 5 & + & + & + & + & + & + & E1 & 0 & + & ND & 0.67 \\
\hline 0634 & 5 & + & + & + & + & + & + & $\mathrm{E} 1$ & 0 & + & $+1-$ & 1.47 \\
\hline $3048^{\mathrm{H} d}$ & 5 & + & + & - & - & - & - & E2 & 41 & + & + & 1.45 \\
\hline 3162 & 5 & + & + & $+1-$ & - & - & - & E2 & 41 & + & + & 2.83 \\
\hline 3294 & 5 & + & + & $+1-$ & - & - & - & E2 & 41 & + & + & 1.64 \\
\hline 3328 & 5 & + & + & - & - & - & - & E2 & 41 & + & ND & 1.66 \\
\hline 5436 & 5 & ND & ND & ND & ND & ND & ND & E2 & 41 & + & + & 2.83 \\
\hline 0498 & Here & + & + & + & - & - & - & $? ?$ & 0 & + & - & 0.10 \\
\hline 6774 & 5 & + & + & + & + & + & + & $? ?$ & 0 & + & - & 0.33 \\
\hline 6572 & 5 & + & + & + & + & + & + & ?? & 0 & + & - & 0.08 \\
\hline \multicolumn{13}{|l|}{$X$. citri } \\
\hline 3210 & Here & + & + & + & ND & ND & + & citri & ND & $+t$ & - & OTS \\
\hline $3213^{\mathrm{T}}$ & Here & + & + & + & + & + & + & citri & ND & ++ & - & OTS \\
\hline \multicolumn{13}{|c|}{$X$. campestris pv. alfalfae } \\
\hline $\mathrm{KX}-1$ & 16 & + & + & + & - & - & $-*$ & $? ?$ & ND & $+1-$ & ++ & 0.50 \\
\hline Ona & Here & + & + & + & - & - & $-*$ & $? ?$ & ND & $+1-$ & ++ & 0.46 \\
\hline L-334 & Here & + & + & + & - & - & -* $^{*}$ & $? ?$ & ND & - & ++ & 0.15 \\
\hline L-676 & Here & + & + & + & - & - &  & ?? & ND & - & ++ & 0.58 \\
\hline 82.1 & Here & + & + & + & - & - & $-*$ & $? ?$ & ND & ND & ++ & ND \\
\hline \multicolumn{13}{|l|}{$X$. phaseoli } \\
\hline $\mathrm{G}-27^{\mathrm{I}}$ & 16 & + & + & + & - & - & - & phaseoli & ND & - & - & 0.00 \\
\hline \multicolumn{13}{|l|}{$X$. campestris pv. } \\
\hline $13 \mathrm{D} 5$ & 16 & + & + & + & + & + & + & $? ?$ & ND & - & - & 0.00 \\
\hline
\end{tabular}

${ }^{a}$ Three different pectin media were used to detect pectinase activity: Hildebrandt minimal sodium polypectate medium (10) adjusted to ca. $\mathrm{pH} 5.0$ (pH 5.0 pectin) or $\mathrm{pH} 7.0$ (pH 7.0 pectin) and fluorescent pseudomonas agar (19), a nutritionally rich medium supplemented with citrus pectin (FPA pectin). *, Precipitation zone around colonies.

${ }^{b}$ Pathogenicity tests were run in double-blind experiments. Whole-plant assay results are reported in comparison with the most-pathogenic strains on indicated hosts $(++$, strong pathogenic response elicited on host plant, typical of that elicited by the most-pathogenic xanthomonad known to attack that host when ca. $10^{5} \mathrm{CFU} / \mathrm{ml}$ inoculations are used; + , weak pathogenic response; + +- , much weaker pathogenic response; - , no apparent pathogenic response). For detached-leaf assays, the numbers correlate with the relative degree of tissue damage (chlorosis plus necrosis) on a scale of 0 (low) to 3 (high). The numerical score is the average of six tests. OTS, Off the scale (since $X$. citri elicits entirely different and more dramatic symptoms).

ND, Not determined.

d Holopathotype.

performed by inoculating washed cells into alfalfa, bean, and citrus plants. Some of these tests were performed in doubleblind experiments and were previously reported (5). Pathogenicity test comparisons of a larger group of $X$. campestris pv. citrumelo strains with controls of $X$. citri, $X$. phaseoli, $X$. campestris pv. cyamopsidis and $X$. campestris pv. alfalfae on $M$. sativa cv. Florida 77 and $C$. paradisi $\mathrm{cv}$. Duncan (grapefruit) are presented in Table 1.

In pathogenicity tests on alfalfa, strains of the E1 group, strains $498,6774,6572$, and all control strains ( $X$. campestris pv. cyamopsidis and $X$. campestris pv. alfalfae) tested elicited no or poor symptoms on alfalfa plants when inoculated at low concentrations, while all E2 strains tested elicited symptoms which were indistinguishable from those elicited by $X$. campestris pv. alfalfae strains (5). These symptoms included early water soaking, followed by tissue collapse and necrosis that spread to the leaf margins. In pathogenicity tests on citrus, the strains of $X$. campestris pv. alfalfae tested elicited symptoms ranging from none to intermediate when inoculated at low concentrations and compared with those elicited by $X$. campestris pv. citrumelo strains. It should be noted that $X$. citri strains elicit dramatically different symptoms from those caused by $X$. campestris pv. citrumelo and $X$. campestris pv. alfalfae on citrus, including rapidly developing tissue hyperplasia, central necrosis, and surrounding-tissue chlorosis. Although the symptoms elicited by $X$. campestris pv. citrumelo and $X$. campestris pv. alfalfae strains were comparable in these tests (tiny green-to-red-brown lesions that appeared to be water soaked under magnification), the symptoms elicited by $X$. citri strains were not comparable to those of any of the other strains tested. All control strains were negative on citrus 


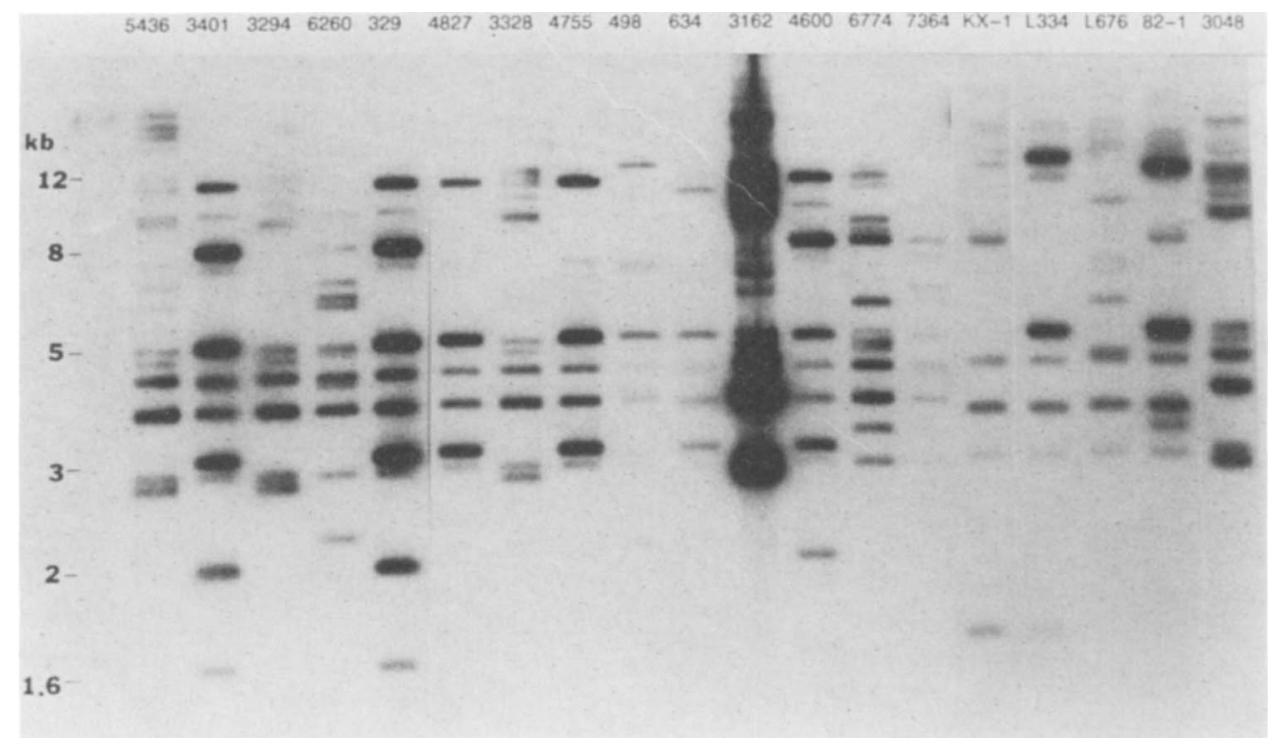

FIG. 1. Autoradiographs of $X$. campestris pv. citrumelo and $X$. campestris pv. alfalfae total DNAs extracted from strains described in Table 1, digested with EcoRI, and probed with pUFT1. kb, Kilobases.

when inoculated at the low concentrations used $\left(10^{4}\right.$ to $10^{5}$ $\mathrm{CFU} / \mathrm{ml})$.

Detached citrus leaf pathogenicity tests. All strains of $X$. campestris pv. alfalfae tested elicited pathogenic reactions in detached citrus leaf assays that were well within the range of those caused by $X$. campestris pv. citrumelo strains (Table 1). These experiments were performed double blind with coded samples. The detached-leaf assay was useful for distinguishing strains of $X$. phaseoli and $X$. campestris pv. cyamopsidis from $X$. campestris pv. citrumelo strains, but $X$. campestris pv. alfalfae strains were not distinguished from $X$. campestris pv. citrumelo strains. All symptoms were compared with those caused by $X$. campestris pv. citrumelo strains, for which the rating scale was developed.

TABLE 2. Similarity coefficients of the combined data on $X$. campestris pv. citrumelo strains $^{a}$

\begin{tabular}{|c|c|c|c|c|c|c|c|c|c|c|c|c|c|c|}
\hline \multirow{3}{*}{ Strain } & \multicolumn{14}{|c|}{$\%$ Similarity with: } \\
\hline & \multicolumn{7}{|c|}{ E1 group strains } & \multicolumn{4}{|c|}{ E2 group strains } & \multicolumn{3}{|c|}{ Other strains } \\
\hline & 0329 & 4600 & 4755 & 4827 & 6260 & 7364 & 0634 & 3162 & 3294 & 3328 & 5436 & 0498 & 6572 & 6774 \\
\hline 3401 & 100 & 97 & 65 & 61 & 63 & 55 & 58 & 25 & 41 & 49 & 26 & 33 & 50 & 50 \\
\hline 0329 & & 100 & 77 & 72 & 66 & 61 & 59 & 38 & 34 & 49 & 29 & 49 & 53 & 50 \\
\hline 4600 & & & 76 & 64 & 61 & 49 & 59 & 19 & 26 & 33 & 52 & 47 & 48 & 56 \\
\hline 4755 & & & & 76 & 53 & 50 & 56 & 32 & 35 & 45 & 43 & 49 & 43 & 56 \\
\hline 4827 & & & & & 49 & 49 & 75 & 33 & 43 & 50 & 55 & 57 & 38 & 53 \\
\hline 6260 & & & & & & 82 & 47 & 40 & 33 & 42 & 44 & 27 & 44 & 50 \\
\hline 7364 & & & & & & & 47 & 32 & 46 & 33 & 47 & 43 & 50 & 58 \\
\hline 0634 & & & & & & & & 33 & 36 & 44 & 41 & 53 & 31 & 40 \\
\hline 3162 & & & & & & & & & 91 & 90 & 97 & 33 & 41 & 53 \\
\hline 3294 & & & & & & & & & & 97 & 89 & 36 & 40 & 53 \\
\hline 3328 & & & & & & & & & & & 92 & 45 & 32 & 56 \\
\hline 5436 & & & & & & & & & & & & 31 & 38 & 50 \\
\hline 0498 & & & & & & & & & & & & & 37 & 37 \\
\hline 6572 & & & & & & & & & & & & & & 60 \\
\hline
\end{tabular}

${ }^{a}$ The data are from probes pUFA704 and pUFT1, each hybridized against DNAs cut with EcoRI and (separately) BamHI, as illustrated in Fig. 1. Coefficients were calculated as described in the text.
Comparisons on citrus were not made relative to $X$. citri, which elicits a dramatic hyperplastic response that is not comparable to the response elicited by any of the other strains tested.

Growth kinetics on two bean cultivars. Growth curves of representative $X$. campestris pv. citrumelo strains on two bean cultivars, starting from low inoculum levels, in comparisons with $X$. phaseoli, $X$. campestris pv. alfalfae (positive controls), $X$. campestris pv. malvacearum, and $X$. citri (negative controls) are shown in Fig. $3 a$ and $b$. The results are shown as the average of three replications, with standard errors. Of the strains tested, $X$. phaseoli grew to the highest levels and appeared to become systemic with time, as previously reported (2). $X$. campestris pv. citrumelo and $X$. campestris pv. alfalfae strains grew at comparable rates but did not appear to become systemic and did not achieve the same levels of cells as $X$. phaseoli in the plant (possibly because they were more localized and we assayed the whole leaf). A strong cultivar-specific effect was noticed in the interactions with the $X$. campestris pv. citrumelo and $X$. campestris pv. alfalfae strains; that is, cv. Contender (Fig. $3 b)$ was more resistant to these strains than was cv. California Light Red (Fig. 3a). The symptoms induced by $X$. phaseoli, $X$. campestris pv. alfalfae and $X$. campestris pv. citrumelo appeared to be macroscopically identical. The $X$. citri and $X$. campestris pv. malvacearum strains tested did

TABLE 3. Similarity coefficients of the combined data on $X$. campestris pv. citrumelo 4600 and 3048 and $X$. campestris pv. alfalfae $\mathrm{KX}-1, \mathrm{~L} 334,82-1$, and ${\mathrm{L} 676^{a}}^{a}$

\begin{tabular}{lccccc}
\hline \multirow{2}{*}{ Strain } & \multicolumn{5}{c}{ \% Similarity with: } \\
\cline { 2 - 6 } & L334 & $82-1$ & L676 & 4600 & 3048 \\
\hline KX-1 & 66 & 71 & 53 & 45 & 40 \\
L334 & & 66 & 50 & 39 & 55 \\
$82-1$ & & & 40 & 47 & 41 \\
L676 & & & & 39 & 31 \\
4600 & & & & & 40 \\
\hline
\end{tabular}

${ }^{a}$ The data were derived as described in Table 1 , footnote $a$. 


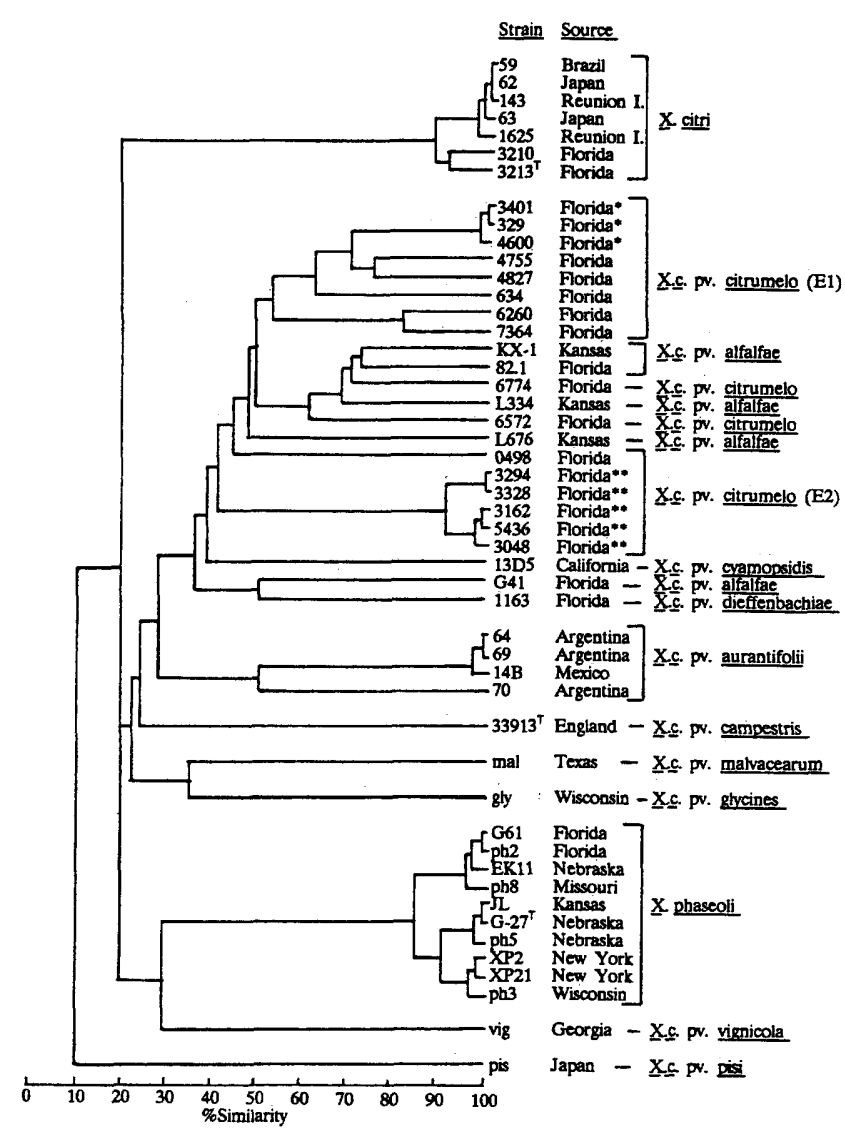

FIG. 2. Dendrogram obtained by unweighted average pair group clustering of similarity coefficients. Each of the 48 strains was characterized by RFLP analyses with at least two DNA probes. Coefficients for $X$. citri, $X$. phaseoli, $X$. campestris pv. aurantifolii, $X$. campestris pv. malvacearum, $X$. campestris pv. glycines, $X$. campestris $\mathrm{pv}$. vignicola, and $X$. campestris $\mathrm{pv}$. pisi were previously published (5). Coefficients for some $X$. phaseoli strains and the $X$. campestris pv. campestris type strain were derived from previously published data (16). * and $* *$ indicate strains that may have been spread by shipment of host materials rather than by natural means. A superscript $T$ indicates a type strain.

not multiply well in either bean cultivar tested or produce visible symptoms when inoculated at low levels.

Growth kinetics on citrus. Growth kinetic tests were also performed on Duncan grapefruit plants, although under more limiting conditions. Experimental inoculations of these plants could be performed only at a BL-3P level of containment until recently, when experiments with $X$. campestris pv. citrumelo strains were allowed under BL-2P conditions. Shown in Fig. 3c are the results of inoculation of grapefruit plants with various Xanthomonas strains. In terms of macroscopic symptoms elicited from the host, the $X$. citri strain was most obviously pathogenic, distantly followed by the $X$. campestris pv. citrumelo strain, followed by $X$. campestris pv. alfalfae. The $X$. campestris pv. malvacearum strain elicited a slight hypersensitivity response in the host, and the $X$. campestris pv. phaseoli strain gave virtually no host response. As expected, the $X$. citri strain multiplied best in this citrus host, followed closely by $X$. campestris pv. citrumelo 3048 . The $X$. campestris pv. malvacearum and $X$. phaseoli strains tested were apparently unable to multiply for more than four cell divisions in Duncan grapefruit leaves, and the symptoms elicited by each were correlated with the degree of their apparent survival after inoculation (Fig. 3c). Growth curves on Duncan grapefruit distinguished X. campestris pv. citrumelo 3048 from the $X$. campestris pv. alfalfae strain tested. The holopathotype strain of $X$. campestris pv. citrumelo is 3048 , deposited in the American Type Culture Collection as ATCC 49120.

\section{DISCUSSION}

Initial RFLP analyses focused on comparisons between previously described $X$. campestris pv. citri strains and strains isolated from Florida citrus nurseries (5). The $X$. citri group of strains and the $X$. campestris pv. aurantifolii strains B and D composed two separate and highly clonal groups, readily distinguishable by qualitative RFLP comparisons from over 100 strains of 26 other pathovars of $X$. campestris $(5,16)$, including 17 strains of $X$. campestris pv. campestris (J. E. Hunter, D. W. Gabriel, A. Alvarez, and G. Lazo, manuscript in preparation). The single extant $X$. campestris pv. aurantifolii $C$ strain is somewhat related to the $B / D$ strains of the pathovar. The type strain of $X$. campestris, ATCC $33913^{\mathrm{T}}$, exhibited a distinctive RFLP pattern (data not shown) which was ca. $20 \%$ similar to the strains tested by RFLP analyses and reported in Fig. 2. Strains of $X$. campestris pv. citrumelo were readily distinguishable from $X$. citri, $X$. campestris pv. aurantifolii, and many other pathovars. Unlike the $X$. citri and $X$. phaseoli strains, however, the $X$. campestris pv. citrumelo strains were heterogeneous and were not distinguished from strains of $X$. campestris pv. alfalfae, another heterogeneous group.

When RFLP comparisons are made between strains not readily distinguished by common microbial tests, the question arises of setting some objective criterion for separating the strains into taxonomically valid groups. There is a number of ways groups may be defined, e.g., by protein (27) or DNA restriction enzyme (9) electrophoretic patterns, by multilocus enzyme (22), or by RFLP analyses. For RFLP analyses; the choice of probes is critical; some probes reveal very little polymorphism, while others reveal much. The criterion we suggest for inclusion of a Xanthomonas strain in a species is at least $80 \%$ similarity with the type strain as determined with test probes proven capable of revealing $20 \%$ or less similarity between species of the genus. Since similarity coefficients are relative numerical values, coefficients based on RFLP comparisons must be derived from DNAs separated on the same gel. The derived coefficients are consistent and reproducible from gel to gel, provided the same restriction enzyme-probe combinations are used. Therefore, strain clusters derived from different gels may be grouped into combined dendrograms by clustering the clusters if cross-reference strains are provided on each gel.

For strains of the genus Xanthomonas with less than $80 \%$ similarity with a type strain or another group of strains, the RFLP test provides insufficient information for classification at the species or pathovar level. It is possible that such strains cannot be meaningfully or usefully classified at the pathovar level even by pathogenicity tests. Strains with a high clonal identity, such as $X$. citri and $X$. phaseoli, also elicit specific, well-defined pathogenicity phenotypes; and classification of these strains is consistent by either phenotypic criterion. However, strains with less than $80 \%$ similarity to other strains by RFLP analyses may also be pathologically dissimilar. We could not distinguish all strains of $X$. campestris pv. citrumelo from all strains of $X$. campestris pv. alfalfae by RFLP comparisons, detached-leaf assays, and/or whole-plant pathogenicity tests. Variation in the 

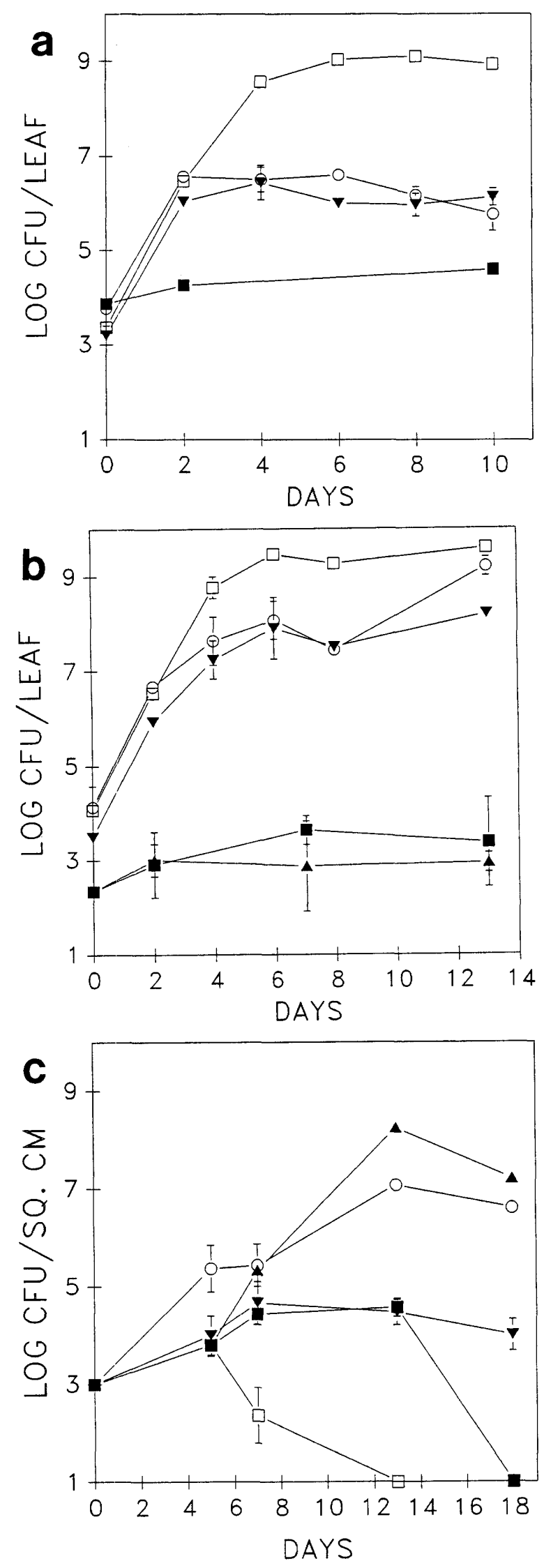

pathogenicity of $X$. campestris pv. citrumelo strains on citrus is so high that there is not even a widely accepted definition of the disease that could be used to classify unknown strains. Some of these strains are so weakly pathogenic to citrus that they may have been only incidentally isolated from citrus. The $X$. campestris pv. citrumelo epiphytotic disease was (and still is) widespread in Florida (21) and was caused by strains never before described on rutaceous hosts. Recurring infections have been found in Florida every year since 1984 despite an intensive inspection-and-eradication effort. This strongly suggests that the primary or source host(s) is not citrus. At present, inclusion of strains in $X$. campestris pv. citrumelo and $X$. campestris pv. alfalfae is based solely on "the host plant from which first isolated" (25).

Developing objective criteria for circumscribing pathovars is a major problem. Since detached-leaf assays and even greenhouse pathogenicity tests are based on host response, they may be artifactual indicators of reproductive fitness in field situations (29). Some plants may react to incompatible $X$. campestris strains with a hypersensitivite response that is so similar to the normal (normosensitivite) response (12) of compatible strains that there may be no indication that the reaction is one of incompatibility. This is especially true when high concentrations of bacteria are inoculated. Short of field tests, which were not allowed with $X$. campestris pv. citrumelo strains until recently, a more ecologically relevant assay of pathogenicity may be growth kinetics on an intact host. We therefore decided to use pathogen growth kinetics in plants as an assay of basic reproductive ability.

Initial growth kinetic studies were of the $X$. campestris pv. citrumelo strains on alfalfa plants. Unfortunately, cultivars of alfalfa are really mixtures of many different genotypes. Although rapid growth of some $X$. campestris pv. citrumelo strains was observed on some alfalfa plants, replications of leaf inoculation data were highly variable. As an alternative indicator of parasitic fitness on legumes, $P$. vulgaris (common bean) was chosen for these assays. $P$. vulgaris is reportedly within the host species range of several pathovars of $X$. campestris, including $X$. campestris pv. alfalfae, $X$. campestris pv. armoraciae, $X$. campestris pv. glycines, $X$. campestris pv. phaseoli, and $X$. campestris pv. vignicola (1). Growth kinetic studies and pathogenicity tests with two bean cultivars indicated that all of the $X$. campestris pv. citrumelo strains tested were indistinguishable from the $X$. campestris pv. alfalfae strains tested (cf. Fig. $3 a$ and b). On citrus, however, the $X$. campestris pv. alfalfae strain grew more poorly than the $X$. campestris pv. citrumelo strain tested. Whether or this observation is strain dependent or a general property of the pathovars is unknown at this point, since growth kinetic studies are tedious to perform.

Based on the relationships revealed in the dendrogram of Xanthomonas strains presented in Fig. 2, we conclude that there is sufficient justification to separate the clonally distinguishable strains now considered as pathovars of $X$. campestris into separate species of the genus. In particular, it is clear that $X$. citri and $X$. phaseoli (not including $X$. campe-

FIG. 3. Growth kinetics of Xanthomonas strains following inoculation in two $P$. vulgaris cultivars and one $C$. paradisi variety. (a) Growth in $P$. vulgaris cv. Contender. (b) Growth in $P$. vulgaris cv. California Light Red. (c) Growth in $C$. paradisi var. Duncan. Symbols: $\square, X$. phaseoli $\mathrm{G}-27^{\mathrm{T}} ; \mathbf{\Lambda}, X$. citri $3213^{\mathrm{T}} ; \mathbf{\square}, X$. campestris pv. malvacearum $\mathrm{N} ; \mathrm{O},=X$. campestris pv. citrumelo $3048 ; \boldsymbol{\nabla}, X$. campestris pv. alfalfae $\mathrm{KX}-1$. 
stris pv. phaseoli var. fuscans) form very homogeneous clonal groups and that these clonal groups are distinct from the type strain of the species, $X$. campestris pv. campestris. We propose that these defined clonal groups be reinstated as species. Strains of $X$. campestris pv. phaseoli var. fuscans are clearly distinct from the $X$. phaseoli strains (16), and the former should probably be considered as $X$. campestris pv. fuscans. Finally, $X$. campestris pv. campestris itself, including the type strain, may be a clonal group and constitute a distinct subbranch of the genus. The diverse pathovars now included in this species may more appropriately be considered as pathovars of another, perhaps unnamed, species of the genus. A designation such as Xanthomonas sp. pv. alfalfae, e.g., without reference to a name suggestive of pathogenicity on Brassica campestris, may be less confusing.

$X$. phaseoli (ex Smith) nom. rev. The description of $X$. phaseoli is the same as for the genus. The following description is based on previously published data concerning the genus (1) and on our own work with 10 strains from six of the continental United States; all studies included the type strain. Cells are straight rods, usually within the range of 0.4 to $0.7 \mu \mathrm{m}$ wide by 0.7 to $1.8 \mu \mathrm{m}$ long. Gram negative. Motile by a single polar flagellum. Obligately aerobic. Optimum growth temperature is $30^{\circ} \mathrm{C}$, with no growth above $38^{\circ} \mathrm{C}$. On agar plates, colonies are circular, raised, semitranslucent, and yellow and the margins are entire. The pigments are brominated aryl polyenes or xanthomonadins, and crude methanol extractions of the pigments exhibit a major absorption peak between 443 and $446 \mathrm{~nm}$. Able to use a variety of carbohydrates and salts of organic acids as sole carbon sources. No amino acids required for growth. Growth on minimal media greatly stimulated by addition of glutamic acid. Starch and casein hydrolysis positive; lipolysis of Tween 80 . No evidence of pectinase activity in culture (cf. Table 1). Distinguished from $X$. campestris and $X$. citri by distinct patterns of hybridizing DNA bands by RFLP analyses (cf. Fig. 2). Isolated from bean ( $P$. vulgaris L.) plants showing a systemic blight disease of leaves and pods. The type strain is G27, deposited in the American Type Culture Collection as ATCC 49119.

$X$. citri (ex Hasse) nom. rev. The description of $X$. citri is the same as for the genus. The following description is based on previously published data concerning the genus (1) and on our own work with seven strains from four countries; all studies included the type strain. Cells are straight rods, usually within the range of 0.4 to $0.7 \mu \mathrm{m}$ wide by 0.7 to 1.8 $\mu \mathrm{m}$ long. Gram negative. Motile by a single polar flagellum. Obligately aerobic. Optimum growth temperature is $30^{\circ} \mathrm{C}$, with no growth above $38^{\circ} \mathrm{C}$. On agar plates, colonies are circular, raised, semitranslucent, and yellow and the margins are entire. The pigments are brominated aryl polyenes or xanthomonadins, and crude methanol extractions of the pigments exhibit a major absorption peak between 443 and $446 \mathrm{~nm}$. Able to use a variety of carbohydrates and salts of organic acids as sole carbon sources. No amino acids required for growth. Growth on minimal media greatly stimulated by addition of glutamic acid. Starch and casein hydrolysis positive; lipolysis of Tween 80 . Strong pectinase activity in culture, particularly evident on Hildebrandt minimal sodium polypectate medium (10). Distinguished from $X$. campestris and $X$. phaseoli by distinct pattern of hybridizing DNA bands by RFLP analyses (cf. Fig. 2). Isolated from various genera within the family Rutaceae, including $P$. trifoliata, Citrus sinensis, $C$. paradisi, C. limon (lemon), $C$. reticulata, and $C$. aurantifolia, causing a canker disease on twigs, leaf spotting and defoliation, fruit spotting and premature fruit drop, and a general decline of both nursery stock and mature trees. The type strain is 3213 , deposited in the American Type Culture Collection as ATCC 49118.

\section{ACKNOWLEDGMENTS}

We thank N. Schaad, M. Schroth, and A. Alvarez for suggesting the proposal to rename the species and $\mathrm{C}$. Schoulties for numerous helpful discussions. We also thank T. Reily and M. Hojjati for excellent technical assistance. We are also grateful for the generous gifts of bean seed from J. A. Laurence, Boyce Thompson Institute, Cornell University, Ithaca, N.Y., and K. Maslyn, Agway Corporation Beanplant, Ithaca, N.Y.

This work was supported by USDA-58-7B30-3-465.

\section{LITERATURE CITED}

1. Bradbury, J. F. 1984. Xanthomonas Dowson 1939, p. 199-210. In N. R. Krieg and J. G. Holt (ed.), Bergey's manual of systematic bacteriology, vol 1. The Williams \& Wilkins Co., Baltimore.

2. Cafati, C. R., and A. W. Saettler. 1980. Effect of host on multiplication and distribution of bean common blight bacteria. Phytopathology 70:675-679.

3. Civerolo, E. L. 1984. Bacterial canker disease of citrus. J. Rio Grande Val. Hortic. Soc. 37:127-146.

4. Claflin, L. E., M. D. Sasser, and A. K. Vidaver. 1985. MXP, a semi-selective medium for Xanthomonas campestris pv. phaseoli. Phytopathology 75:1360.

5. Gabriel, D. W., J. Hunter, M. Kingsley, J. Miller, and G. Lazo. 1988. Clonal population structure of Xanthomonas campestris and genetic diversity among citrus canker strains. Mol. PlantMicrobe Interact. 1:59-65.

6. Gerhardt, P., R. E. E. Murray, R. N. Costilow, E. W. Nester, W. A. Wood, N. R. Krieg, and G. B. Phillips. 1981. Manual of methods for general bacteriology. American Society for Microbiology, Washington, D.C.

7. Goto, M., T. Takahashi, and M. A. Messina. 1980. A comparative study of the strains of Xanthomonas campestris pv. citri isolated from citrus canker in Japan and cancrosis B in Argentina. Phytopathol. Soc. Jpn. 46:329-338.

8. Gottwald, T. R., E. L. Civerolo, S. M. Garnsey, R. H. Brlansky, J. H. Graham, and D. W. Gabriel. 1988. Dynamics and spatial distribution of Xanthomonas campestris pv. citri group $\mathrm{E}$ strains in simulated nursery and new grove situations. Plant Dis. 72:781-787.

9. Hartung, J. S., and E. L. Civerolo. 1987. Genomic fingerprints of Xanthomonas campestris pv. citri strains from Asia, South America and Florida. Phytopathology 77:282-285.

10. Hildebrand, D. C. 1971 . Pectate and pectin gels for differentiation of Pseudomonas sp. and other bacterial plant pathogens. Phytopathology 62:1430-1436.

11. Johnson, J. L. 1984. Nucleic acids in bacterial classification, p. 8-11. In N. R. Krieg and J. G. Holt (ed.), Bergey's manual of systematic bacteriology, vol. 1. The Williams \& Wilkins Co., Baltimore.

12. Klement, Z. 1982. Hypersensitivity, p. 149-177. In M. S. Mount and G. H. Lacy (ed.), Phytopathogenic prokaryotes, vol. II. Academic Press, Inc., New York.

13. Lapage, S. P., P. H. A. Sneath, E. F. Lessel, V. B. D. Skerman, H. P. R. Seeliger, and W. A. Clark. 1975. International code of nomenclature of bacteria. American Society for Microbiology, Washington, D.C.

14. Lazo, G. R., and D. W. Gabriel. 1987. Conservation of plasmid DNA sequences and pathovar identification of strains of Xanthomonas campestris. Phytopathology 77:448-453.

15. Lazo, G. R., D. W. Gabriel, and R. Roffey. 1986. Differentiating pathovars of Xanthomonas campestris without pathogenicity tests. Phytopathology 76:1076.

16. Lazo, G. R., R. Roffey, and D. W. Gabriel. 1987. Pathovars of Xanthomonas campestris are distinguishable by restriction fragment length polymorphisms. Int. J. Syst. Bacteriol. 37:214-221.

17. Lennette, E. H., E. H. Spaulding, and J. P. Truant. 1974. 
Manual of clinical microbiology, 2nd ed. American Society for Microbiology, Washington, D.C.

18. Neidhardt, I. C., P. L. Bloch, and D. F. Smith. 1974. Culture medium for enterobacteria. J. Bacteriol. 119:736-747.

19. Sands, D. C., L. Hankin, and M. Zucker. 1972. A selective medium for pectolytic fluorescent pseudomonads. Phytopathology 62:998-1000.

20. Schleifer, K. H., and E. Stackebrandt. 1983. Molecular systematics of prokaryotes. Annu. Rev. Microbiol. 37:143-187.

21. Schoulties, C. L., E. L. Civerolo, J. W. Miller, R. E. Stall, C. J. Krass, S. R. Poe, and E. P. DuCharme. 1987. Citrus Canker in Florida. Plant Dis. 71:388-394.

22. Selander, R. K. 1985 . Protein polymorphism and the genetic structure of natural populations of bacteria, p. 85-106. In T. Ohta and K. Aoki (ed.), Population genetics and molecular evolution. Japan Scientific Societies Press, Tokyo.

23. Sneath, P. H. A., and R. R. Sokal. 1973. Numerical taxonomy. The principles and practice of numerical classification. W. H. Freeman \& Co., San Francisco.

24. Stall, R. E., and C. P. Seymour. 1983. Canker, a threat to citrus in the gulf-coast states. Plant Dis. 67:581-585.

25. Starr, M. P. 1983. The genus Xanthomonas, p. 742-763. In M. P. Starr (ed.), The prokaryotes: a handbook on habitats, isolation, and identification of bacteria. Springer-Verlag, New York.

26. Swings, J., P. De Vos, M. Van Den Mooter, and J. De Ley. 1983. Transfer of Pseudomonas maltophilia Hugh 1981 to the genus Xanthomonas as Xanthomonas maltophilia (Hugh 1981) comb. nov. Int. J. Syst. Bacteriol. 33:409-413.

27. Thaveechai, N., and N. W. Schaad. 1986. Serological and electrophoretic analysis of a membrane protein extract of Xanthomonas campestris pv. campestris from Thailand. Phytopathology 76:139-147.

28. Wishart, D. 1987. Clustan user manual, 4th ed. Computing Laboratory, University of St. Andrews, Fife, Scotland.

29. Yuen, G. Y., A. M. Alvarez, A. A. Benedict, and K. J. Trotter. 1987. Use of monoclonal antibodies to monitor the dissemination of Xanthomonas campestris pv campestris. Phytopathology 77:366-370. 